\title{
The Effect of Computational Thinking Module on Achievement in Science
}

\author{
Noraini Lapawi*, Hazrati Husnin \\ Centre of Teaching and Learning Innovation National University of Malaysia, Malaysia
}

*Corresponding Author: norainilapawi@gmail.com

\section{ABSTRACT}

Computational thinking (CT) is a problem-solving process and argued to be one of the more important skills for the $21^{\text {st }}$ century. This study aimed to identify the effectiveness of the Science Module on achievement in science subjects. A quasi-experimental research design was used that involved 67 students in the first form in secondary schools (students aged 13) in the Kunak district of Malaysia. The students were divided into a treatment group $(n=36)$ and a control group $(n=31)$. The instrument used in this study was the Science Achievement Test for Matter. The treatment group received an intervention of 3-week instruction using the Science Module and the control group received conventional instruction. Both groups took a pre-test before treatment. After the treatment, a post-test was administered. The study's results were analyzed with inference statistics and using a t-test. The study revealed that there was a significant improvement in science achievement after using Science Module. The study indicated that the effectiveness of Science Module is an effective step toward enhancing achievement in science and thus should be applied in Science, Technology, Engineering, and Mathematics teaching and learning to solve complex problems.

KEY WORDS: computational thinking, computational thinking module, problem-solving, science education

\section{INTRODUCTION}

T

Transformation in science education is growing in tandem with the development of $21^{\text {st }}$-century education that integrates $4 \mathrm{C}$ elements of communication, critical thinking skills, collaboration, and creativity (Ministry of Education, 2017). Science education is a key ingredient to enable the workforce to compete in the industrial revolution (IR) 4.0, the umbrella term for the revolutionary application of biotechnologies, alternative fuel technology, nanotechnology, new materials, and other recent breakthroughs to industrial production. The IR 4.0 combining automation and cyber technology require students to have a higher level of thinking skills, computational thinking (CT), problem-solving skills, creative, innovative, as well good Information Communication Technology (ICT) skills. CT skills can be used to break problems down into smaller components to help solve them (Swaid, 2015). Using Scratch for teaching and learning can link learning to real life. The isolation of everyday life elements in the classroom learning process makes it difficult for students to apply the knowledge gained in real life (Akınoğlu and Tandoğan, 2007). Therefore, science education should serve as a catalyst for developing students who are not only knowledgeable in science and technology but also have a range of soft skills.

Science Module integrates CT skills by incorporating pluggedin CT skills. The plugged-in Science Module was implemented using a computer through the computer programming of Scratch 3.0 in the topic "Matter" in Form One science subjects. The teaching approach is plugged-in using Scratch. Scratch is a visual tool used for teaching and programming activities that gives novice programmers the opportunity to understand a basic concept such as variables, logic structures, event-driven processing, and debugging (Yukselturk and Altiok, 2016). Interestingly enough, Scratch programming is very useful because factors such as visual interface, pedagogy, and CT provide an engaging learning platform that is even easier to use (Saltan and Kara, 2016; Yukselturk and Altiok, 2016). In addition, previous studies have shown that CT skills through Scratch enable students to solve problems and understand a concept (Kalelioğlu and Gülbahar, 2014; Moreno-León and Robles, 2015; Su et al., 2014).

This module was based on the collaboration and use of ICT. This module used the application Scratch to increase the level of interest in teaching and learning while also enhancing CT and the integration of CT in science subjects. Scratch applications are well known for developing students CT skills as they have several elements of CT such as decomposition, pattern recognition, abstraction, generalization, algorithm, and evaluation in solving problems. Scratch is a graphical programming language and an environmentally friendly, effective, and attractive programming language for teaching coding (Werner et al., 2014) and was developed by the Lifelong Kindergarten Group at MIT Media Laboratory (Zaranis et al., 2016). There is a lot of support from past studies that show "Matter," as a topic in science, is a difficult topic to master and has caused conceptual errors because particles are invisible to the naked eye and require students to imagine them. Findings 
of Lajium et al. (2005) show that misconceptions occur when students believe that: Changes in Matter cause material mass change, atoms can be destroyed under normal conditions, or temperature and changes in the state of Matter result in a material change of Matter.

A pre-study needs analysis conducted with 20 teachers and 72 students indicated that Matter was a difficult topic in science education; $65 \%$ of teacher thought that it was difficult, as did $69 \%$ of students. Table 1 shows the level of difficulty of the study in the Standards-based Curriculum for Secondary Schools (KSSM) science subjects form one according to the perceptions of teachers and students. For those with the highest meanings, the topics are considered difficult. Based on Table 1, it was found that there was a similar perception between students and teachers that the subject "Matter" was difficult.

The result reveals that teachers $(75 \%)$ and students $(85 \%)$ considered the printed module alone was sufficient for understanding this topic. The needs analysis also showed that a large majority of teachers $(65 \%)$ and students $(95 \%)$ agreed that computerized visual learning was needed for teaching and learning. Visual learning may help teachers overcome student misconceptions, such as increased particle size and more as the image or visual. Besides that, the students can develop in Scratch programming may provide a more concrete and accurate understanding of the changes that Matter may undergo. Through the study of Rohana (2006) that computer animation of the topic Matter is a proposed method to overcome the difficulties of delivering teacher teaching while helping students to learn more easily and effectively. In the study of Dalhar and Ali (2009), it was found that it is difficult for most students to use imagination for intangible elements with rudimentary views and difficult to describe. Table 2 and Table 3 show the module elements proposed by teachers and students when performing the needs analysis.

Therefore, interventions need to be implemented and focus should be given to help students master the basic concepts of physical properties and chemical properties of the three physical states and the changing order of their particles. It aims to introduce the elements of nature made up of Matter.

\begin{tabular}{|c|c|c|c|c|}
\hline \multirow[t]{2}{*}{ Learning area } & \multicolumn{2}{|c|}{ Student } & \multicolumn{2}{|c|}{ Teacher } \\
\hline & M & SD & M & SD \\
\hline \multicolumn{5}{|c|}{ Introduction to scientific investigation } \\
\hline Cells as a basic life unit & 2.17 & 0.53 & 1.85 & 0.67 \\
\hline Coordination and response & 2.83 & 0.41 & 2.35 & 0.49 \\
\hline Reproduction & 2.72 & 0.63 & 2.50 & 0.61 \\
\hline Matter & 3.99 & 0.57 & 3.65 & 0.49 \\
\hline Periodic table & 3.51 & 0.61 & 3.10 & 0.55 \\
\hline The air & 2.31 & 0.57 & 2.05 & 0.76 \\
\hline Light and optic & 2.89 & 0.57 & 2.80 & 0.62 \\
\hline Earth & 1.97 & 0.56 & 1.50 & 0.51 \\
\hline
\end{tabular}

This mastery also helps students master in other topics such as periodic table and the air that include elements of nature and basic concepts to students in the fourth level chemistry subject at Atomic Structure.

The purpose of this study is to develop a Science Module on improving CT in form one science subjects using the Matter topic. This study has two objectives:

1. Develop a Science Module in the Matter topic; and

2. Evaluate the effectiveness of the Science Module on achievement in the Matter topic.

To address the objectives of the study, the conventional teaching and learning approach needed to be transformed into a studentcentered approach with the use of ICT such as Science Module. The use of computer programming like Scratch in science subjects can be integrated with CT. The computer information technology used in teaching and learning should be well designed to teach more effectively, increase motivation, and enhance the knowledge and CT skills for students. CT skills through Scratch enable students to have the critical thinking, creative and innovative ideas and even solve problems. Therefore, this study investigates how pupils can develop their thinking processes and reflect on their own cognitive processes to produce meaningful learning experiences.

\section{CT}

Fundamentally, the term CT was introduced by Jeannette Wing, a computer science scientist in 2006. The goal of this approach is to promote thinking like a computer scientist among the general public, but Wing did not provide a universal definition for CT (Wing, 2006; Selby and Woollard, 2010). However, the results of the literature review by Selby and Woollard (2010) found that there was a consensus in the definition of $\mathrm{CT}$ as a form of thinking process involving the process of scaling and dissolving information. In 2012, Wing

\begin{tabular}{lcc}
\hline \multicolumn{3}{l}{ Table 2: The module element proposed by the teachers } \\
\hline Element module & $\begin{array}{c}\text { Percentage of } \\
\text { teachers agreed (\%) }\end{array}$ & $\begin{array}{c}\text { Percentage of } \\
\text { teachers disagree (\%) }\end{array}$ \\
\hline Cooperative learning & 95 & 5 \\
Simulation & 95 & 5 \\
Visualization & 95 & 5 \\
Printed module TMK & 85 & 15 \\
Power point & 70 & 30 \\
Print module only & 20 & 80 \\
\hline
\end{tabular}

Table 3: The module element proposed by the students

\begin{tabular}{lcc}
\hline Element module & $\begin{array}{c}\text { Percentage of } \\
\text { students agreed (\%) }\end{array}$ & $\begin{array}{c}\text { Percentage of } \\
\text { students disagree (\%) }\end{array}$ \\
\hline Cooperative learning & 52.7 & 47.4 \\
Simulation & 83.3 & 16.7 \\
Visualization & 89.5 & 10.5 \\
Printed module TMK & 68.4 & 31.6 \\
Power point & 70 & 30 \\
Print module only & 33.3 & 66.7
\end{tabular}


described CT as a thought process and one of the branches of problem-solving skills. According to her, these skills are seen as a necessity for every individual in today's digital age as they encourage creativity and innovation and are well applied in the context of complex problem-solving (Wing, 2012).

$\mathrm{CT}$ is a cognitive or thinking process that requires logical thinking in which problems are solved, procedures, and systems are better understood (Csizmadia et al., 2015). The power of CT not only reveals how to solve problems but also critical thinking, creative, logical, formulate problemsolving processes that enable computers to improve human ability to solve problems while also developing attitudes, self-confidence, and communication International Society for Technology in Education (ISTE, 2011). Hence, the role of CT is not just to recognize Computer Science to $\mathrm{CT}$ as programming but rather to make CT a part of our lives (Voogt et al., 2015).

\section{CT in the Context of Malaysia}

In the context of education in Malaysia, CT was first introduced through the Basic Computer Science (ASK) subject in form one (students aged 13) that began to be offered in 2017 after Integrated Curriculum for Secondary School (KBSM) was replaced by Standard Based Curriculum for Secondary School (KSSM). In this subject, students are exposed to basic techniques in CT, pattern recognition, scaling, and repetition (Samudin et al., 2016). These four basic techniques are in accordance with the operating definition guidelines issued by ISTE and Computer Science Teachers Association (CSTA) in the United States. This should be seen as a good start to the development of CT in the education system in Malaysia as it is a highly thought-provoking process, especially for training students with more challenging high-level thinking and skills. An introduction to the basics of CT techniques enables it to be applied not only in computer science but also in other Science, Technology, Engineering, and Mathematics (STEM) subjects (Lee et al., 2016; Weintrop et al., 2016; Barr et al., 2011). Recognizing that CT capabilities can be applied across curriculum and disciplines, this thinking has been introduced into K-12 education system in the West (Barr and Stephenson, 2014). It is not only focused on computer science but also has expanded into other areas of science. The ISTE in collaboration with the CSTA has collaborated on a project to formulate the concept of CT that is applicable to K-12 education in line with classroom education goals and practices (Barr et al., 2011). What ISTE and CSTA can conclude is that CT is a problem-solving process that involves: (1) The process of formulating problems that allow computers or other tools to be used to solve, (2) logical management and data analysis, (3) data representation through scaling, (4) automation through a series of algorithms, (5) identify, analyze, and implement reasonable solutions through efficient and effective methods and resources, and (6) generalize problem-solving processes to a broader scope of problems.

A teaching transformation needs to be made by the teacher so that the misconceptions or alternative concepts of student-related Matter are transformed into scientific concepts
(Lajium et al., 2005). Misconceptions arise as a result of inaccurate or alternative concepts that students perceive to be true and appropriate to their existing knowledge or experience and are true to their daily life. Alternative conceptual or conceptual issues are often present in the instruction concerning the topic of Matter. For example, through the study of Lajium et al. (2005) showed that students still think that changes in the shape of Matter are the cause of a change in mass of Matter, atoms can be destroyed under normal conditions, temperature, and changes in Matter state cause material change. This is because teaching and learning in science subjects using the conventional approach is to memorize improperly not suitable and cause students are having understanding abstract concepts of science such as in Matter Topic. Salmiza and Haslinda (2015) stated in a study conducted that students often classify substances based on the physical properties of the substances and assume that not all substances are composed of particles.

The next issue to be solved through the development of this module concerns the effectiveness of visualization methods in teaching and learning topics. It is both difficult for many students to use their imagination to imagine things that are not visible to their eyes and then to portray it on paper (Baharuddin et al., 2006). Computerized animations of the Matter topic are one of the proposed methods to overcome the difficulties of delivering teaching while helping students to learn more easily and effectively. Furthermore, some studies support the effectiveness of visualization methods in teaching and learning such as visual learning in improving students' understanding of learning mathematics (Wan Muda, 2017); three-dimensional visualization software to assist students with the low spatial ability to study Biological science subjects (Che et al., 2015); and Lasiun (2016) study emphasized the effectiveness of visualization methods to help improve the ability to solve life-long mathematics problems among students of dual-level cognitive levels in rural areas.

Kamaruddin et al. (2006) found that $22.78 \%$ of students/ teachers were able to give an explanation correctly, while the other half had no idea in regards Matter. This is possible because the term is common, but it describes an abstract and elusive concept. However, the real meaning of Matter is that it consists of any material that has mass and space. Instruction in the topic of Matter includes examples of the states of Matter, their characteristics, and their changes in state. Previous studies highlight students' learning of the concept of Matter.

This illustrates that Matter is a difficult topic and requires more than just a printed module for students to understand. From the analysis of the needs also found that element of teachers (Table 2) agreed on the need for visualization of computer $(95 \%)$ and students $(89.5 \%)$ in teaching and learning. Based on previous results (Tables 1-3), researchers propose the ability to use more modern methods to teach science subjects such as module strategies. In addition, teachers will need to provide courses and training workshops to implement module strategies. Therefore, the module strategy provides textbooks 
and references that the convenience of this teaching style. The teaching module is a systematic way of thinking in dealing with all the factors involved in the teaching and learning process. The importance of developing science teaching methods is part of how to implement the curriculum and achieve its purpose with different content and activities and to switch from teaching science from conventional methods to modern concepts. The idea of applying modern teaching methods and diversity such as module methods and strategies is considered appropriate for science subjects (Alelaimat and Raheem Ghoneem, 2012).

\section{Application of CT Worldwide}

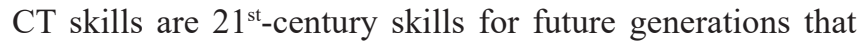
came to be developed (Seneviratne, 2017). However, less focus been made in terms of integrating CT skills with science subjects as a way to solve more complex problems. Today, most countries around the world have implemented a computerized curriculum that contains elements of Computer Science. In studying Computer Science, students not only gain knowledge but also their uniqueness in how to think and solve problems through CT skills (Curzon et al., 2019). The idea of introducing computer programming in the classroom was introduced in the 1960 s by Papert. At that time, Papert and MIT College developed LOGO programming for children (Bers, 2018). According to Bers (2018), programming gives students the opportunity to engage in logic, abstract thinking, problem-solving, and creative design processes.

$\mathrm{CT}$ is growing rapidly around the world through the involvement of non-governmental organizations to adapt programming in the curriculum and promote participation in Computer Science. A literature review of students understanding of the basic science concepts in categories, synthesis, and summary was conducted by Duit (2004) to study the holistic apprehension of the concepts. This study found that teachers did not effectively identify the misconceptions that students held, particularly in the early learning classroom (Costa et al., 2000). Teachers, therefore, must develop a strong interest in introducing appropriate methods to reduce student misconceptions of the basic concepts of science in line with their learning approach. Doing so may help promote positive attitudes and increase interest in science subjects (Harrison and Treagust, 2001).

Studies on CT that use computer programming are extremely critical in formal environments to provide students with the opportunity to develop their cognitive skills with problemsolving skills using CT approaches (Basu et al., 2017). However, many studies are conducted without the guidance and implementation guidelines that make programming successful without involving the cognitive thinking involved in each step taken (Basu et al., 2017). Skills related to this aspect of cognition are important in CT but have been underestimated by researchers in research related to CT (Lye and Koh, 2014). Science researchers are less aware of students' weakness and strengths and rarely perform student needs analysis, including consideration of their cognitive abilities and learning styles in designing teaching approaches (Chen and Osman, 2016).

\section{Conceptual Framework}

The conceptual framework of this study is based on variables, theories, models, and concepts that have the same focus relevant in producing effective synergy to achieve the objectives of the study outlined. The conceptual framework in this study provided an overview of the variables and theories used in the research. The Science Module used two theories, namely, the theory of Constructivism and Constructionism. This study was also based on the Social Constructivism Theory (Vygotsky, 1978) which emphasized the importance of the relationship between individuals in the social environment. According to Vygotsky, social interaction between one individual to other individuals is important in the development of students cognitive skills. Vygotsky argued that the learning process would be more effective if students learned collaboratively in which they were guided by other students who were more capable than themselves, as well as with the help of teachers. A summary of the descriptions of the conceptual framework of the study is shown in Figure 1.

Based in the conceptual framework illustrated in Figure 1, this study developed the following research questions: Is the Science Module effectiveness in improving achievement in the Matter topic and Is the Science Module effective in CT in the Matter topic? Following the research question, the study developed the following null hypotheses:

$\mathrm{H}_{01}$ : There is no significant effect of improving achievement in the Matter topic

$\mathrm{H}_{02}$ : There is no significant effect on $\mathrm{CT}$ in the Matter topic.

\section{METHODOLOGY}

\section{Research Design}

This study was a quasi-experimental field study conducted outside the laboratory (Cohen et al., 2007). Experimental quizzes involved experiments conducted on field interventions with a random selection of groups and using classes. This is because researchers did not interfere with the school's existing administrative system. Students remained in their respective classes during the intervention. There was a disturbance when researchers formed a new class with the concept of random

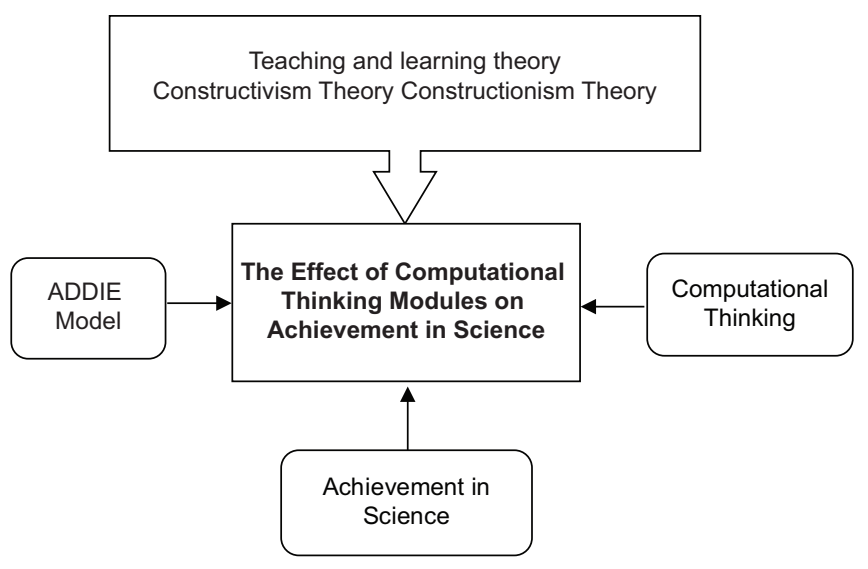

Figure 1: Research conceptual framework 
distribution in actual experimental studies. However, a study involving a random selection of students for the control and treatment groups is currently underway. Design of pre-test and post-test control and treatment groups are shown in Table 4.

There are two types of teaching approaches that were implemented: The traditional or conventional and the Science Module approach. Participants in the control group studied the subject of Matter using a conventional approach. Conventional teaching approaches using existing learning materials such as textbooks provided by Ministry of Education Malaysia (MOE), computers and teachers' teaching and learning approaches also use higher-order thinking (HOT) questions that require problem-solving among students as emphasized by the MOE. Participants in the treatment group using the Science Module consisted of one group. The purpose of this study was to compare the effectiveness of the Science Module on achievement in the subject of science and CT in science. Therefore, this study involved one independent variable: (1) Group and two dependent variables that were measured were (1) achievement in the subject Matter and (2) CT in science.

\section{Samples}

The study was conducted in the district of Kunak, in the Tawau Division of Sabah, Malaysia, and all students in the study population were from form 1 year of students (13-year-old age), with a total study group of 67 students. The criteria for this study were as follows:

1. Only form one students in Kunak

2. School with computer laboratory

3. Science teacher with at least 5 years of teaching experience in science subjects.

The achievement test was administered twice, namely, a pretest and post-test administered to the participating students. The pre-test was used to determine students existing knowledge and the homogeneity of the two treatments and control groups in the subject of Matter before the intervention. The post-achievement test was used to test the effectiveness of the Science Module in improving achievement compared to conventional methods. The two science teachers involved in this study were experienced teachers who had been teaching science for more than 5 years.

\section{Instrument}

The achievement test was used to evaluate the effectiveness of the Science Module on student knowledge of the subject of Matter. A pre-test and post-test were administered in this study. Both sets of questions have the same number of questions, type of questions, difficulty level, and scope. The pre-test was administered before the intervention and the post-test after the intervention. The format of the test was based on the Form

\begin{tabular}{llll}
\hline \multicolumn{4}{l}{ Table } \\
4: & Quasi-experimental design & \\
\hline Groups & Pre-test & Intervention & Post-test \\
\hline Control & U1 & Conventional approach & U2 \\
Treatment & U1 & Using Science Module & U2 \\
\hline
\end{tabular}

Three Assessment (PT3) requirement and on the Standard Document of Curriculum and Assessment of Form 1 (DSKP) (Ministry of Education, 2015a) which consisted of multi-form objective questions (Ministry of Education, 2014a). The open response questions which were the HOT questions asked the students to analysis the data, give ideas based on the correct concepts, evaluate, and provide the reasoning behind their choice. In addition, these items were taken from form one science textbooks and reference books and collection of actual examination questions based on the PT3 format developed by Ministry of Education (2014b).

The questions developed in the pre-test and post-test were based on the Test Specification Table which is based on Bloom's Taxonomy consisting of six categories, namely, knowledge, understanding, applying, analyzing, evaluating, and creating. The scope of the content in the pre-test and post-test questions ensured that the questions covered all of the teaching and learning that was covered in the course. The pre-test and post-test questions were made up of two forms: Objective questions and essays. There are fifteen objective questions and three essay questions in both pre-test and post-test. The validity of the content in the test questions was evaluated and reviewed by two experts comprising experienced teachers and excellent teachers in science subjects. The scoring rubric provides analytic and holistic scoring methods for the test and was based on the DSKP (Ministry of Education, 2015b). In this study, the researchers used quasi-experimental design and results were analyzed with inference statistics and using a t-test to determine whether there were significant mean differences in the use of Science Modules in achievement and CT. As illustrated in Table 5, a summary of the instruments was used in assessing the effectiveness of the Science Module.

\section{FINDINGS}

Table 6 shows the descriptive statistics of the mean postachievement scores by group. The mean post-achievement score of the control group, $\mathrm{M}=12.548(\mathrm{SP}=2.706)$ while the mean post-achievement score of the treatment group, $\mathrm{M}=18.333$ $(\mathrm{SP}=3.985)$. The mean post-treatment achievement score exceeded the control group means achievement score of 5.785.

The Levene test was first implemented to determine whether there was a difference in achievement after the intervention. Table 7 shows that the result of the Levene test for the variance of the homogeneity for the post-achievement test was not significant $(F=2.350, \rho=0.130)$. This shows that the difference

\begin{tabular}{llll}
\hline \multicolumn{3}{l}{$\begin{array}{l}\text { Table 5: Instruments in pre-test, post-test, and } \\
\text { intervention }\end{array}$} \\
\hline Groups & Pre-test & Intervention & Post-test \\
\hline Control & $\begin{array}{l}\text { Science } \\
\text { achievement test }\end{array}$ & $\begin{array}{l}\text { Conventional } \\
\text { approach }\end{array}$ & $\begin{array}{l}\text { Science } \\
\text { achievement test }\end{array}$ \\
Treatment & $\begin{array}{l}\text { Science } \\
\text { achievement test }\end{array}$ & $\begin{array}{l}\text { Using science } \\
\text { module }\end{array}$ & $\begin{array}{l}\text { Science } \\
\text { achievement test }\end{array}$ \\
\hline
\end{tabular}


Table 6: Descriptive statistics mean group postachievement scores by group

\begin{tabular}{lccc}
\hline Groups & Mean (\%) & Standard deviation & $\mathbf{n}$ \\
\hline Control & 31.38 & 6.78 & 31 \\
Treatment & 45.82 & 9.98 & 36 \\
\hline
\end{tabular}

Table 7: Levene test for homogeneity variance for post science achievement

\begin{tabular}{lcc}
\hline Dependent variable & F & Sig. $(\rho)$ \\
\hline Post-achievement test & 2.350 & 0.130 \\
\hline
\end{tabular}

between the control and treatment groups was the same as the variance assumed.

The results of the analysis found that there was a significant difference in mean post-achievement scores between the control and treatment groups $(\mathrm{t}=-6.835$ and $\mathrm{df}=65$, $\rho<0.05$ ). The results show that the treatment groups have an impact on science achievement, which is effective after the intervention was given to the group in improving student science achievement.

\section{DISCUSSION}

The findings suggested that the Science Module approach was effective in increasing students' achievement in science. Technology increases productivity and motivation supports indirect teaching and unique teaching abilities and enhances information literacy (Roblyer and Schwier, 2003). This indicates the importance of using technology-based teaching modules. Science subjects require creativity and alternative presentations that support animation and visualizations so that students can more clearly and easily understand scientific concepts.

In relation to this, it has also been suggested that that the computational thinking modules approach (Wing, 2006) has the potential to be applied across the curriculum as part of the $21^{\text {st }}$-century instructional styles or thinking approaches. This was confirmed by Bower et al. (2017), who also pointed out that CT should be integrated into the curriculum, as it is a universal skill and competence that all children should possess. Previous studies have found that issues related to low or unsatisfactory scientific motivation, interest, achievement, and perceptions among students (Lay and Kamisah, 2018) contributed by teaching methodologies, subject difficulty, and low science literacy (Kamisah et al., 2007) can be overcome if students are given the opportunity to become involved in cognitive processes more consciously and more actively. They should be exposed to more systematic and practical thinking skills to apply high-level thinking, promote their ability to succeed and perform critical evaluation not only in relation to the STEM subjects but also in other fields. In this context, CT can be useful to all students. Therefore, modules that integrate CT skills in structured and systematic Science are needed as a guide in the classroom (Ung et al., 2018). Continuing with the demands and needs of this education, this study was conducted to contribute to the development of CT skills through science subjects. The role of teachers to guide the development of CT should also be given priority (Alba and Huett, 2017) in make the activity successful and develop CT skills in students. In addition, students want good teachers and are able to tell you what makes a good teacher for them (Sexton, 2017). In fact, to create excitement and to stimulate students' curiosity to engage them in learning, all depends on the activities of the teaching and learning itself. More importantly, teachers need to understand not only the content they convey to their students but also the pedagogy behind how their students learn (Bell and Sexton, 2018).

\section{CONCLUSION}

The aim of the study was to identify the effectiveness of Science Module on achievement in science subject. The study found that the Science Module approach was effective in helping secondary students increase on achievement on in science subjects. Therefore, the adoption of $\mathrm{CT}$ in the teaching and learning of science subjects is very relevant as it can provide teachers with input on the thinking process experienced by students and their application in problem-solving through an inquiry approach. It is hoped that this study will further enhance the problem-solving skills among students as well as promoting student achievement in science subjects and its potential to be applied across the curriculum as one of the $21^{\text {st }}$-century styles or thinking processes. This learning approach is expected to create a stimulating learning environment and experience for students. Thus, further enhance their existing educational practices as it is a highly thought-provoking process, especially for training students with more challenging high-level thinking techniques and skills today.

\section{REFERENCES}

Akınoğlu, O., \& Tandoğan, R.Ö. (2007). The effects of problem-based active learning in science education on students' academic achievement, attitude and concept. Eurasia, 3(1), 71-81.

Alba, A.D., \& Huett, K.C. (2017). Learning computatioanl skills in uCode (a) UWG: challenge and recommendations. Emerging Research Practice and Policy on Computational Thinking, 2017, 3-20.

Alelaimat, A.R., \& Al Raheem Ghoneem, K.A. (2012). The effect of educational modules strategy on the direct and postponed study's achievement of seventh primary grade students in science, in comparison with the conventional approach. Higher Education Studies, 2(2), 40-60.

Baharuddin, A., Bilal, A.M., Jamalludin, H., Zaidatun, T., Azean, A.N., \& Norah, M.N. (2006). E-learning research and development experiences related to learning computer science, information technology and multimedia subjects. In: $3^{\text {rd }}$ International Conference on University Learning and Teaching (InCULT 2006) Theme: World Class Universities: Challenges and Perspectives in Higher Education. Malaysia: University Technology Malaysia.

Barr, D., Harrison, J., \& Conery, L. (2011). Computational thinking: A digital age skill for everyone. Learning and Leading with Technology, $38(6), 20-23$.

Barr, V., \& Stephenson, C. (2014). Bringing Computational Thinking to K12; What is Involved and What is the Role of Computer Science Education Community? ACM Inroads, 2(1), 48-54. 
Basu, S., Biswas, G., \& Kinnebrew, J.S. (2017). Learner modeling for adaptive scaffolding in a computational thinking-based science learning environment. User Modeling and User Adapted Interaction, 27(1), 5-53.

Bell, S.E., \& Sexton S.S. (2018). Science education professional development for primary/elementary teachers: A tale of two systems. Science Education International, 29(2), 117-123.

Bers, M.U. (2018). Coding and computational thinking in early childhood: The impact of scratchjr in Europe. European Journal of STEM Education, 3(3), 1-13.

Bower, M., Wood, L.N., Lai, J.W.M., Highfield, K., Veal, J., Howe, C., Lister, R., \& Mason, R. (2017). Improving the computational thinking pedagogical capabilities of school teachers. Australian Journal of Teacher Education, 42(3), 53-72.

Che, S.S., Umar, I.N., Muniandy, B., Desa, S., \& Hanafi, H.F. (2015). Threedimensional visualization software applications in learning biological sciences: Implications for students with different spatial capabilities. Journal of Science and Mathematics Education Malaysia, 5(1), 57-69.

Chen, C.W.C., \& Osman, K. (2016). The effect of Kayeu learning outside the classroom primary science module on intrinsic motivation of indigenous learners. Journal of Baltic Science Education, 15(3), 360-370.

Cohen, L., Manion, L., \& Morrison, K. (2007). Research Methods in Education. $6^{\text {th }}$ ed. United Kingdom: Routledge Taylor \& Francis Group.

Costa, N., Marques, L. \& Kempa, R., (2000). Science teachers' awareness of findings from educational research. Chemistry Education, 1(1), 31-36.

Csizmadia, A., Curzon, P., Dorling, M., Humphreys, S., Ng, T., Selby, C., \& Woollard, J. (2015). Computational Thinking: A Guide for Teachers. United Kingdom: Computing At School.

Curzon, P., McOwan, P.W., Cutts, Q.I., \& Bell, T. (2009). Enthusing and inspiring with reusable kinaesthetic activities. In: Proceedings of the Conference on Integrating Technology in to Computer Science Education, ITiCSE. New York, United States: Association for Computing Machinery. pp. 94-98.

Dalhar, N.M., \& Ali, M.B. (2009). Self-taught Learning tool for $4^{\text {th }}$ Grade Subject Matter Based on Cognitive. Malaysia: University of Technology Malaysia Publisher.

Duit, R. (2004). Bibliography Students and Teachers Conceptions and Science Education. IPN Kiel. Available from: http://www.ipn.uni-kiel. de/aktuell/stcse/bibint.html. [Last accessed on 2019 Aug 20].

Harrison, A.G., \& Treagust, D.F. (2001). Conceptual change using multiple interpretive perspectives: Two case studies in secondary school chemistry. Instructional Science, 29(1991), 45-85.

ISTE. (2011). Computational Thinking: Leadership Toolkit. Available from: https://www.id.iste.org/docs/ct-documents/ct-leadershipt-toolkit. pdf?sfvrsn=4. [Last accessed on 2019 Jul 22].

Kalelioğlu, F., \& Gülbahar, Y. (2014). The effects of teaching programming via scratch on problem solving skills: A discussion from learners' perspective. Informatics in Education, 13(1), 33-50.

Kamaruddin, I.M., Ambrosse, M.S., \& Ling, H.L. (2006). Mastery of Chemical Terms and Its Relation to Molecular Conflict Resolution: A Case Study Among Two Graduate Students in Chemical Education at the Faculty of Education, University of Technology, Malaysia. Malaysia: University of Technology.

Kamisah, O., Zanaton, I., \& Lilia, H. (2007). Attitudes toward science and scientific attitudes among science students. Journal of Education, 32, 39-60.

Khairul, B.A.K. (2015). An Exploratory Analysis of the Understanding of the Concepts of Matter and Heat in Elementary School Students. Malaysia: Faculty of Science and Mathematics: Sultan Idris Education University.

Lajium, D.A.D., Ismail, Z., \& Yunus, H.M. (2005). Mastery of the Concept of Something in the form Four Students. Pulau Pinang: Education Conference JPPG. pp. 1-9.

Lasiun, M. (2016). Effectiveness of visualization methods: Improving the ability to solve lifetime mathematical problems. Proceeding of ICECRS, 1(2016), 687-698.

Lay, A.N., \& Kamisah, O. (2018). Chemical Education through Designing Games: Theory and Practice. Malaysia: National University of Malaysia.

Lee, I., Martin, F., Denner, J., Coulter, B., Allan, W., Erickson, J., MalynSmith, J., \& Werner, L. (2016). Computational thinking for youth in practice. ACM Inroads, 2(1), 32-37.
Lye, S., \& Koh, L.J. (2014). Review on Teaching and Learning of Computational Thinking Through Programming. What is Next for K-12? Available from: https://www.sciencedirect.com/science/article/ pii/S0747563214004634. [Last accessed on 2019 Jul 17].

Ministry of Education. (2014a). Press Release Ministry of Education Malaysia Related Assessment form 3 2014. Available from: https:// www.moe.gov.my/notification/statement-media/press-ministryeducationmalaysia-related-assessment-3-year-old-2014. [Last accessed on 2018 Oct 10].

Ministry of Education. (2014b). KSSR; Standard-based Curriculum and Assessment Document Science Tahun 6. Putrajaya: Ministry of Education.

Ministry of Education. (2015a). Standard-based Curriculum and Assessment Document Science form 1. Putrajaya: Ministry of Education.

Ministry of Education. (2015b). Standard-based Curriculum and Assessment Document Science form 1. Putrajaya: Curriculum Development Division, Ministry of Education.

Ministry of Education. (2017). Standard-based Curriculum for Secondary Schools: Standard-Based Curriculum and Assessment Document form 3. Putrajaya: Ministry of Education.

Moreno-León, J., \& Robles, G. (2015). Dr. Scratch: A Web Tool to Automatically Evaluate Scratch Projects. Vol. 9. London, United Kingdom. p132-133.

Roblyer, M.D., \& Schwier, R. (2003). Integrating Educational Technology in to Teaching. New Jersey, United States: Prentice Hall.

Rohana, A.W. (2006). Development of Teaching Aids Through Computerized Animation for the Title of Chemistry, Chemistry four Forms. Malaysia: Master's thesis, Faculty of Education of the Malaysian Technology.

Salmiza, S., \& Haslinda, A. (2015). Studies on the understanding of form four students on the concepts of physics and particles. Asia Pacific Journal of Educators and Education, 30, 89-104.

Saltan, F., \& Kara, M. (2016). Higher Education Studies. Higher Education Studies, 6(4), 146-55.

Samudin, K., Looi, K.F., \& Tham, Y.M. (2016). Basics of Computer Science form One. Malaysia: Printing Rina Sdn Bhd.

Selby, C.C., \& Woollard, J. (2010). Computational Thinking: The Developing Definition. New York, United States: ACM.

Seneviratne, O. (2017). Making computer science attractive to high school girls with computational thinking approaches: A case study oshani. In: Rich, P.J., \& Hodges. C.B., (Eds.), Emerging Computational and Policy on Research, Practice, Thinking. Educational Communications and Technology: Issues and Innovations. Cham, Switzerland: Springer International Publishing. pp. 21-32

Sexton, S. (2017). Meaningful intersections of social justice and contemporary cultural competencies in a New Zealand master's level initial teacher education programme. Journal of Contemporary Educational Research, 1(1), 33-42.

Su, A.Y.S., Yang, S.J.H., Hwang, W.Y., \& Huang, C.S.J. (2014). Scratch programming pedagogy. British Journal of Educational Technology, 45(4), 647-665.

Swaid, S.I. (2015). Science Direct Bringing Computational Thinking to STEM Education. Available from: http://www.sciencedirect.com. [Last accessed on 2019 Aug 20].

Ung, L.L., Tammie, C.S., Nasrah, N., Jane, L., \& Norazilah, A.A. (2018). An evaluation tool to measure computational thinking skills: Pilot investigation. Herald NAMSCA, 1, 606-614.

Voogt, J., Fisser, P., Good, J., Mishra, P., \& Yadav, A. (2015). Computational thinking in compulsory education: Towards an agenda for research and practice. Education and Information Technologies, 20, 715-728.

Vygotsky, L.S. (1978). Mind and Society: The Development of Higher Psychological Processes. United States: Harvard University Press.

Wan Muda, H.N.W. (2017). Visual Learning Methods in Effort to Increase Self-Understanding of Mathematics Subjects II. Faculty of Technical and Vocational Education. Malaysia: Tun Hussien Onn University of Malaysia.

Weintrop, D., Beheshti, E., Horn, M., Orton, K., Jona, K., Trouille, L., \& Wilensky, U. (2016). Defining computational thinking for mathematics and science classrooms. Journal of Science Education and Technology, $25,127-147$

Werner, L., Denner, J., \& Campe, S. (2014). Children programming games: 
A Strategy for Measuring. ACM Transactions on Computing Education, $14(4), 1-22$.

Wing, J.M. (2006). Computational Thinking. Communications of the ACM, 49(3), 33-35.

Wing, J.M. (2012). Computational Thinking. In: Microsoft Research Asia Faculty Summit. China: Tianjin University.

Yukselturk, E., \& Altiok, S. (2016). An investigation of the effects of programming with Scratch on the preservice IT teachers' self-efficacy perceptions and attitudes towards computer programming. British Journal of Educational Technology, 48(3), 789-801.

Zaranis, N., Papadakis, S.J., Kalogiannakis, M., \& Orfanakis, V. (2016). Using scratch and app inventor for teaching introductory programming in secondary education. A case study. International Journal of Technology Enhanced Learning, 8(3), 217-233. 